\title{
Respect for Judicial Precedent as a Limit on the Exercise of Public Power
}

\author{
Santiago Legarre
}

\begin{abstract}
This article first explains where Argentina fits in the common law-civil law divide of legal families. A proper understanding of the Argentine legal system regarding precedent makes it necessary to next elaborate on the distinction between the horizontal and the vertical dimensions of stare decisis. I also examine the relevance of political interferences for compliance by other courts both in the horizontal and in the vertical dimensions just alluded.The article briefly highlights features of some Latin countries that impact negatively on the practice of precedent. I shall conclude that, those features notwithstanding, the practice of judicial precedent still constitutes a relevant stop to the abuse of public power by the political branches.
\end{abstract}

\subsection{Introduction}

What Antonio-Carlos Pereira Menaut predicates of the decisions of the Constitutional Tribunal of Spain reveals a fact behooving the decisions of Supreme Courts and Constitutional Tribunals in general: they bind all public powers. ${ }^{1}$ The point I would like to raise in this paper is that, given the truth of that statement, the institution of judicial precedent - under the form of stare decisis, but also under the form of some milder instantiations of precedent that I shall explore here-indirectly limits the exercise of executive and legislative power. As it is an internal practice of the judiciary there is nothing the other branches of government can do about it. Even changes in the personnel of the Supreme Courts (which could indeed be

\footnotetext{
${ }^{1}$ ANTONIO-CARLOS PEREIRA MENAUT, TEMAS DE DERECHO CONSTITUCIONAL ESPAÑOL: UNA VISIÓN PRoblemÁtica, 76 (Follas Novas, Santiago de Compostela, 1996).
}

\footnotetext{
S. Legarre (\&)

Universidad Católica Argentina, Av. Alicia Moreau de Justo 1400,

Ciudad Autonoma de Buenos Aires, Argentina

e-mail: santiagolegarre@uca.edu.ar
} 
initiated by the political branches) will be relatively unimportant, I shall argue, in the presence of some sort of practice of judicial precedent.

I shall first clarify, in Sect. 2, what I mean by the practice of judicial precedent. I think this might be quite appropriate as the intended readership of this book is indeed varied and multinational, and those of us who contribute to it come from such diverse cultural and legal traditions. In the same Sect. 1 will give an example of a civil law jurisdiction with some practice of judicial precedent - the Argentine republic, my own country-one of the milder instantiations of precedent that do not amount to stare decisis.

I will next, in Sect. 3, briefly highlight features of some Latin countries that impact negatively on the practice of precedent. I shall conclude that, those features notwithstanding, the practice of judicial precedent still constitutes a relevant stop to the abuse of public power by the political branches.

\subsection{Dimensions of Stare Decisis}

Stare decisis is a legal principle by which judges are obliged to respect the precedents established by prior decisions. Strictly speaking, it is characteristic of common law countries, as it is well known. According to the traditional English perspective, the compulsory bond exists "whether [the precedent] was handed down the previous year or a century ago, and even if the rule it lays now seems inappropriate because of altered social circumstances or for some other reason." ${ }^{2}$

The principle is of course more sophisticated than my simple formulation, and it involves key, familiar notions such as analogy, distinguishing, ratio decidendi, holding, and obiter dictum. ${ }^{3}$ I would like to highlight here a distinction within stare decisis that often goes overlooked. ${ }^{4}$

If we are describing the obligation of a given court to follow decisions of a court of the same hierarchy, we are in the presence of "horizontal stare decisis". In other words, with horizontal stare decisis, the court bound and the court binding share the same ranking in the judicial system (indeed, they sometimes are the same court at two different points in time).

\footnotetext{
${ }^{2}$ Konrad zWEIGERT and Hein кӧтz, Introduction to Comparative Law, third revised edition, Clarendon Press, Oxford, 1998 (translation from German by T. Weir), 260. See too Arthur L. goodhart, Precedent in English and Continental Law 50 Law QUARTERLy REVIEW 40, 41 (1934). This article, by he who preceded both H.L.A. Hart and R.M. Dworkin in the Jurisprudence chair at Oxford University, is regarded widely as a source of the utmost authority on the topic.

${ }^{3}$ The most authoritative book on stare decisis is Sir Rupert Cross's Precedent in English Law. See RUPERT CROSS WITH JIM W. HARRIS, PRECEDENT IN ENGLISH LAW (Oxford U. Press, 4th ed. 1991).

${ }^{4}$ In what follows I will rely on some of my previously published work. See, especially, Santiago Legarre, Precedent in Argentine Law 57 LOYOLA L. REv. 781 (2011). See too, Santiago Legarre and Julio C. Rivera Jr., Nature and Dimensions of Stare Decisis, in ESSAYS IN HONOR OF SAÚL LITVINOFF, 561 (Olivier Moréteau, Julio Romanach Jr. \& Alberto Luis Zuppi eds. Claitor 2008).
} 
If we are describing the obligation of a given court to follow decisions of a superior court, we are in the presence of "vertical stare decisis." Put another way, with vertical stare decisis, the court bound and the court binding are located at different levels of the judicial system (therefore, they are never the same court at two different points in time.)

Vertical stare decisis is the "central case" of stare decisis because, in the absence of compliance by the lower court, there is a high likelihood that the lower court's decision will be overruled. This works as a kind of sanction against the noncomplying court. On the other hand, horizontal stare decisis is a test case for stare decisis since there is the absence of a sanction for the non-complying court: the persistence of the duty to obey even without the threat of overruling - a duty that indeed persists, even at this horizontal level, in the common law world-shows that that duty does not consist merely of the sheer fear of a sanction. ${ }^{5}$

In some countries, such as the United States, horizontal stare decisis does not apply, strictly speaking, to constitutional matters at the level of the Supreme Court. ${ }^{6}$ It is important to make clear, however, that this exception is not relevant for vertical stare decisis on constitutional matters. With vertical stare decisis, courts are bound by the decisions of upper courts regardless of the subject matter.

This exclusion of constitutional questions from horizontal stare decisis at the level of the Supreme Court reinforces the following idea: whereas vertical stare decisis functions more as a matter of principle, horizontal stare decisis is more a matter of policy. Famous dicta by Justice Brandeis of the United States Supreme Court-such as "[s]tare decisis is not a universal inexorable command" and "[s] tare decisis is usually the wise policy" - are better understood with the notion that horizontal stare decisis is a matter of policy. It is the "wise policy" but only usually. It is a "command" but not an inexorable command. Regardless of their seemingly universal grandeur, these phrases were coined (and subsequently cited ad infinitum) in cases dealing with horizontal stare decisis, not vertical. ${ }^{9}$ On the other hand, it is not true that vertical stare decisis is usually the wise policy; rather, it is something

\footnotetext{
${ }_{5}^{5}$ H. L. A. HART, the CONCEPT OF LAW, 10-11, 16, 213, 217-18 (Oxford U. Press, 2nd ed. 1994).

${ }^{6}$ The reasons for the exclusion of constitutional questions from horizontal stare decisis at the level of the Supreme Court are provided in Justice Brandeis's famous dissent in Burnet v. Coronado Oil and Gas Co. 285 U.S. 393, 406-08 (1932).

${ }^{7} I d$, at 405 .

${ }^{8} I d$, at 406 .

${ }^{9}$ See e.g. the following examples of references to Justice Brandeis's dictum in majority opinions of the United States Supreme Court: "Smith v. Allwright", 321 U.S. 649, 665-666 (1944); "Glidden Co. v. Zdanok", 370 U.S. 530, 543 (1962); "Edelman v. Jordan", 415 U.S. 651, 671 (1974); "Illinois Brick Co. v. Illinois", 431 U.S. 720, 736 (1977); "Monell v. Department of Soc. Svcs.", 436 U.S. 658, 695 (1978); Thomas v. Washington Gas Light Co., 448 U.S. 261, 273, note 18 (1980); "Payne v. Tennessee", 501 U.S. 808, 827-828 (1991); Hubbard v. United States, 513 U.S. 695, 712, note 11 (1995); "Seminole Tribe of Florida v. Florida", 571 U.S. 44, 63 (1996); "Agostini v. Felton”, 521 U.S. 203, 235-236 (1997).
} 
closer to an inexorable command. To state it another way: it is a matter of law, not a matter of policy; it is a legal obligation rather than a moral guideline. ${ }^{10}$

For the purposes of this paper I will shortly turn to the Argentine legal system and analyze if and how precedent works there, both at the horizontal and vertical levels. But before doing so we might as well recall what Cappelletti clarifies in general regarding the civil law world, to which Argentina belongs, by way of contrast with what happens in common law countries. After acknowledging that the absence of a formal stare decisis doctrine in most countries that adopt the civil law system still constitutes an important difference with those governed by common law, the distinguished comparative law scholar asserts:

$[D]$ e facto an auctoritas rerum similiter judicatarum - the authority of precedents - has always been recognized even in the civil law tradition. The difference, in fact, is essentially one of degree, and has to be seen in connection with [...] the more diluted structure of the courts, the flood of irrelevant decisions submerging the few significant ones, the more anonymous and routine-oriented judicial personnel - all these characteristics [belonging to civil law systems] conspire to make that auctoritas less pronounced, less visible, and far less dramatic than the authority of precedents in the areas where the common law tradition prevails. ${ }^{11}$

Indeed in certain civil law jurisdictions, such as my own, there is some form of practice of judicial precedent, even if it does not qualify as stare decisis. Enter the Argentine system of "soft obligation".

If in the United States vertical stare decisis is a matter of principle, in Argentina it is merely a matter of "soft principle." If in the United States horizontal stare decisis is a matter of policy, in Argentina it is too a matter of policy, albeit a relaxed policy.

Let us first analyze how the policy of vertical stare decisis works in Argentina. Whereas in the United States there is an obligation to follow relevant decisions of higher courts of the same jurisdiction, in Argentina there is a soft obligation to do so. "Soft obligation" looks like an oxymoron but it summarizes the truth of the matter. ${ }^{12}$ For even though there is no constitutional rule or custom providing for stare decisis, lower courts in Argentina-both federal and provincial ${ }^{13}$-look at the Argentine Supreme Court's decisions and, for the most part, follow them. Although lower courts agree that there is no constitutional obligation to follow higher

\footnotetext{
${ }^{10}$ JOHN FINNIS, Natural Law and Legal Reasoning, IN ROBERT P. GEORGE, NATURAL LAW THEORY 13457 (Oxford U. Press 1992).

${ }^{11}$ MAURO CAPPELLETTI, THE JUDICIAL PROCESS IN COMPARATIVE PERSPECTIVE 52 (Clarendon Press 1989).

${ }^{12}$ In Spanish the right expression appears to be "obligatoriedad atenuada". See Santiago Legarre \& Julio C. Rivera Jr., La obligatoriedad atenuada de los fallos de la Corte Suprema y el stare decisis vertical, 2009-E L.L. 820, 821 (2009) (Arg.).

${ }^{13}$ Argentina is, at least in theory, a federal system much like the United States. Our "provincias" are similar to states. They have, therefore, courts of their own: provincial courts. Furthermore, unlike state courts in the United States, these provincial courts apply some national law, as explained in Santiago Legarre, A Departure from the Rationale Behind the American System in the Argentine Constitution, 16 RECHTSGESCHICHTE, ZEITSCHRIFT DES MAX-PLANCK-INSTITUTS FÜR EUROPÄISCHE RECHTSGESCHICHTE, 85, 86-87 (2010).
} 
precedent, it is indeed rare that a lower court would decide a case without first checking the Supreme Court's view on the matter. It is even rarer that a lower court would depart from that view-although on occasion it does. ${ }^{14}$

The Supreme Court itself reinforces this understanding of the Argentine judicial system. Although the Court has repeatedly asserted that there is no obligation for lower courts to follow its jurisprudence, the assertion always comes accompanied with a warning: lower courts must not rebel against the authority of Supreme Court precedents; otherwise their decisions shall be struck down. ${ }^{15}$ In practice this boils down to the notion that lower courts are bound to check on the Supreme Court's case law and are bound to follow its relevant precedents. But if a given court finds good reason for departing from supreme jurisprudence, it is entitled to do so. As per the prevailing doctrine of the Supreme Court for the last thirty years or so, a good reason is considered to exist when a lower court finds "new arguments" for deciding the case differently. ${ }^{16}$ When this condition exists, the Supreme Court will likely uphold the lower court's decision if the ruling is judicially sound in light of the newly presented arguments.

Such a system of soft vertical stare decisis is not really stare decisis. ${ }^{17}$ With true stare decisis, a lower court could not legally depart from a prior relevant precedent by claiming the existence of "new arguments". Instead, it is eventually for the higher court, itself, to consider whether those new arguments deserve an overruling of its own precedent. At the same time, a system of soft vertical stare decisis, such as the Argentine system, differs from the typical civil law system. In the Argentine system, lower courts treat decisions of the Supreme Court as generating a prima

\footnotetext{
${ }^{14}$ See Julio C. Rivera Jr. \& Santiago Legarre, La obligatoriedad de los fallos de la Corte Suprema de Justicia de la Nación desde la perspectiva de los tribunales inferiores in LA PRIMACÍA

DE LA PERSONA, 1109 (Jaime Arancibia Mattar \& José Ignacio Martínez Estay eds.

LegalPublishing-AbeledoPerrot 2009) (explaining this issue at length and with more nuances).

${ }^{15}$ Corte Suprema de Justicia de la Nacion [CSJN] [National Supreme Court of Justice], 6/10/1948, "Santín, Jacinto c. Impuestos Internos/recurso extraordinario", Fallos de la Corte [Fallos] (1948212-51, 59) (Arg.).

${ }^{16} \mathrm{On}$ this question the following case is emblematic and it has been consistently followed, at least in theory: Corte Suprema de Justicia de la Nacion [CSJN] [National Supreme Court of Justice], 4/7/1985, "Cerámica San Lorenzo s. incidente de prescripción/ recurso extraordinario", Fallos de la Corte [Fallos] (1985-307-1094) (Arg.).

${ }^{17}$ Professor Garro, an Argentine colleague who teaches at Columbia University in New York City, is of a similar view. Alejandro M. Garro, Eficacia y autoridad del precedente constitucional en América latina: las lecciones del Derecho Comparado, 1989-I REvISTA JURÍDICA DE BUENOS AIRES 22, 23 (1989) (Arg.). This is also the view of Alberto F. Garay and Alejo Toranzo, even if their reasons are not identical to mine. See Los efectos de las sentencias de la Corte Suprema de Justicia de la Nación, 2005-IV J.A. 1093, 1094 (2005) (Arg.). But the view that I share with Garro, Garay and Toranzo is far from unanimous. Respected Argentine scholars think that at the level of the Supreme Court our system is substantially identical to stare decisis. See, e.g., GERMÁN BIDART CAMPOS, II-B TRATADO ELEMENTAL DE DERECHO CONSTITUCIONAL, 561 (Ediar, Buenos Aires, 3rd ed. 2004); Néstor Pedro Sagüés, Eficacia vinculante o no vinculante de la jurisprudencia de la Corte Suprema de Justicia de la Nación, 93 E.D. 891, 892 (1981) (Arg.); ALberto B. BiANChi, 1 CONTROL DE CONSTituCiONALIDAD 353 (Ábaco, Buenos Aires, 2nd ed. 2002).
} 
facie obligation to obey; the Supreme Court accepts the existence of this prima facie obligation. This is true despite the fact that the Supreme Court may release a lower court from that obligation when the lower court finds "new arguments" that call for a departure from a given precedent. Even though the "new arguments" idea would require an independent, more elaborate explanation, which would include exam- ples, I note here that it is different from the common law idea of "distinguishing." Whereas the latter has to do with facts (and factual differences), "new arguments" have to do with law (and differences of legal interpretation).

Let us now analyze how the policy of horizontal stare decisis works in Argentina. As I have already expressed above, this policy is somewhat more relaxed in my country than in the United States. But it is still a policy that makes Argentina a unique piece within the civil law world.

Again, there is no constitutional rule or custom providing for horizontal stare decisis. ${ }^{18}$ Nevertheless, at the appellate level, including the Supreme Court, courts tend to follow prior decisions and treat them, to some extent, as precedent. Whereas in a prototypical civil law court the tribunal would decide every case from scratch, an Argentine court would typically first look at its own precedent before rendering a decision. The statute in question would be the first and, at least in theory, the only concern of a civil law court. In practice, this is not so with an Argentine court. This is especially true of the Argentine Supreme Court, where a crucial element of litigation consists of pointing the Court toward its own prior relevant decisions. ${ }^{19}$

Furthermore, there is no exception regarding constitutional matters at the Argentine Supreme Court (unlike what happens in the United States). ${ }^{20}$ The Argentine supreme tribunal has never held that constitutional matters are excluded from horizontal stare decisis. Horizontal stare decisis, however, has never been formally adopted by the Supreme Court. There has not been a "practice statement," like the one provided by the House of Lords in the United Kingdom. ${ }^{21}$ Nor has there been a uniform pattern on the question, like one can gather from the jurisprudence of the United States Supreme Court. Nevertheless, the tendency to follow prior decisions and to treat them as precedents exists. ${ }^{22}$ Horizontal stare decisis is considered the de facto wiser policy, even if it is somewhat relaxed. This relaxation is even more noteworthy when political interferences occur.

Political interferences affect both horizontal and vertical stare decisis: they confirm the somewhat relaxed nature of the horizontal stare decisis policy, and they

\footnotetext{
${ }^{18}$ Santiago Legarre, La obligatoriedad horizontal de los fallos de la Corte Suprema argentina y el stare decisis, 4 DERECHO PÚBLICO IBEROAMERICANO, Año 2, abril de 2014, 237, 249.

${ }^{19}$ ALBERTO F. GARAY, LA DOCTRINA DEL PRECEDENTE EN LA CORTE SUPREMA, 215 (Abeledo Perrot, Buenos Aires, 2013).

${ }^{20}$ See Legarre, supra note 19, 251.

${ }^{21}$ [1966] 1 WLR 1234. For an explanation of the "practice statement" see Cross, supra note XXXX at 102-08, 114-15.

${ }^{22}$ See e.g., Alberto F. Garay, El precedente judicial en la Corte Suprema, 1 REVISTA JURÍDICA DE LA UNIVERSIDAD DE PALERMO 51, 57-59; 76-77 (1997) (Arg.).
} 
prove that the principle of vertical stare decisis is much weaker in Argentina than in the common law world.

Before explaining what I mean by "political interferences," it will be useful to expose what might be the Achilles' heel of the Argentine system of judicial review. Countries that have adopted a system of judicial review - that is, the vast majority of Western countries - have either concentrated in one court (normally called "Constitutional Tribunal", as it is in the case of Chile, for example) the power to strike down legislation on account of its unconstitutionality (this system is normally called "decentralized") or they have granted that power to all the courts of the system, topping it with a Supreme Court whose decisions bind lower courts under the principle of vertical stare decisis (this system is normally called "decentralized"). Both systems grant (or purport to grant) a certain uniformity and clarity in the interpretation of constitutional law: the former (sometimes known as the

German system), through the erga omnes effect of the decisions of the Constitutional Tribunal; the latter (sometimes known as the American system), through the effect of vertical stare decisis on the decisions of the Supreme Court. ${ }^{23}$

Well, Argentina has apparently chosen a third way: a decentralized system of judicial review, much like the American system, but without a formal recognition of vertical stare decisis. By so doing, it may well have forfeited those universal "desiderata" of uniformity and clarity that both systems thrive to achieve. For it could happen-it does happen-that the Argentine Supreme Court rules on a given constitutional point, but lower courts do not follow suit. The soft obligation doctrine, which permits departure from higher precedent under certain circumstances, opens the door to this possibility. Furthermore, if the constitutional point in question is permeable to political interferences, there is an additional reason to foresee tension on the horizon. When political interferences occur, the soft, vernacular version of vertical stare decisis is at its weakest.

Let me make clear that by "political interferences" I do not mean undue meddling in the judicial process by those who run the country, e.g. the political branches; executive and legislative. I am thinking now within the realm of legality. Even within it, some cases-sometimes termed "hot" cases by the press-are of such a pressing social relevance that ideology and public sentiment often times slip into the reasoning of the judge. It is in such cases were the principle of soft vertical stare decisis suffers most. So it could happen-it has happened-that Argentine judges ignore or, even worse, blatantly contradict Supreme Court precedent. ${ }^{24}$ In sum, the relaxed, Argentine version of stare decisis limps more in the presence of political interferences.

\footnotetext{
${ }^{23}$ See CAPPELLETTI, supra note $11,132$.

${ }^{24}$ For examples, José Sebastián Elias, Massa y la saga de la pesificación: lo bueno,lo malo y lo feo, 2008-II J.A. 1326, 1327 (2008) (Arg.) and see Legarre, supra note 4, 788-791.
} 


\subsection{Attitudes Toward Rules and the Respect for Precedents}

I move now to a different, but connected issue. ${ }^{25}$ One of the salient, forever lingering structural problems in Latin American constitutionalism is the lack of respect for the law (and for the laws). ${ }^{26}$ This legal problem is in reality part of a broader problem: a cultural problem that could aptly be summed up as 'a certain disregard for the rules"27 — which in the case of Argentina is something of an understatement. I wonder whether this pervading attitude might have something to do-in the case of my country - with our partially Italian roots. While in Southern Italy I was told a saying regarding traffic lights: 'In the North,' they told me in Lecce, 'traffic lights are regulative; in Rome, they are orientational; here in the South of Italy... they are decorative.' My academic visits to Lecce did as a matter of fact bring to my memory, and helped me understand, many Argentine social practices. A saying I learnt from an Argentine friend will perhaps show the kinship with its Italian forerunner: "Rules are for the intelligent to notice and for morons to obey"... I hope I will not offend anyone by confessing that when I asked my friend who qualified as "morons" for his purposes, he answered: "Chileans!". I actually consider it a compliment.

This broader, cultural problem-of which Chileans had been absolved by my Argentine friend-is apparent, for instance, when it comes to constitutional reform and constitutional amendments. Take again the example of Argentina. In 1994 an amendment to the constitution was decided due, almost exclusively, to the sheer will of one person to run for another term of office, ${ }^{28}$ and, to a point, due to the will of a people (or a majority of a people), who voted overwhelmingly for the amendment (and later for the reelection of that person, the then president). It was all at the antipodes of "a government of laws, and not of men," ${ }^{29}$ to quote the Bill of Rights of the Constitution of Massachusetts of 1780 .

\footnotetext{
${ }^{25}$ In what follows I will rely on some of my previously published work. See, especially, Santiago Legarre, "New Trends in Latin American Constitutionalism: an Overview" 4 Notre Dame Journal of International \& Comparative Law 1 (2014).

${ }^{26}$ The idea is perfectly conveyed in the title of one the books by Argentine jurist Carlos S. Nino: Un país al margen de la ley, Ariel, Madrid, 2005.

${ }^{27}$ These, incidentally, are the words used in order to describe the famous magician that went by the name of Harry Potter. Perhaps Mr. Potter's ancestors came from my part of the world...? See http://harrypotter.wikia.com/wiki/Slytherin, last visited on 29 April 2015.

${ }^{28}$ The 1853 Argentine constitution banned a second term for then president Menem, who had been elected in 1989. The constitutional amendment of 1994 removed this impediment and in $1995 \mathrm{Mr}$. Menem got his second term, with the massive support of the people of Argentina.

${ }^{29}$ Constitution of Massachusetts, 1780, Art. XXX: In the government of this commonwealth, the legislative department shall never exercise the executive and judicial powers, or either of them; the executive shall never exercise the legislative and judicial powers, or either of them; the judicial shall never exercise the legislative and executive powers, or either of them; to the end it may be $a$ government of laws, and not of men. Emphasis added.
} 
More importantly for our purposes here, the cultural problem underlying the lack of respect for the law also expresses itself in judicial attitudes - and in attitudes toward judicial practices, including the attitudes of non judicial public officials. Although it is true of our countries what a Louisiana judge cleverly said about his own state- "there is no such thing as precedent"30_, in my part of the world the problem is that often it is only the personnel in the courts that determines the outcome of the cases-other judges, other outcomes. ${ }^{31}$ Even without stare decisis, and even within a civil law jurisdictional background, one can (and should) still advocate for some respect for past decisions so that the people will not get the impression that the only thing that matters is who is in charge today. Of course, as already noted, any notion of stability of case law is at its weakest when political interferences occur-something quite common in Latin America. ${ }^{32}$

Let me conclude by insisting that while it is clear that the cultural problem at stake (and its particular expression when it comes to judicial attitudes and practices) wounds the practice of judicial precedent and its potential to limit the exercise of public power, it seems to me that this practice-in any of the instantiations of precedent examined in this paper-provides a useful check on the abuse of power by the political branches.

\section{References}

BIANCHI, ALBERTO B. Control de constitucionalidad (Ábaco, Buenos Aires, 2d ed. 2002).

BIDART CAMPOS, GERMÁN. II-B Tratado elemental de Derecho Constitucional, (Ediar, Buenos Aires, 3rd ed. 2004).

CAPPELLETTI, MAURO The Judicial Process in Comparative Perspective (Clarendon Press 1989).

CROSS, RUPERT WITH HARRIS, JIM W, Precedent in English Law (Oxford U. Press, 4th ed. 1991).

FINNIS, JOHN, Natural Law and Legal Reasoning, in Robert P. George, Natural Law Theory (Oxford U. Press 1992).

GARAY, ALBERTO F. El precedente judicial en la Corte Suprema, 1 Revista Jurídica de la Universidad de Palermo (1997) (Arg.).

GARAY, ALBERTO F. La Doctrina del Precedente en la Corte Suprema, (Abeledo Perrot, Buenos Aires, 2013).

GARRO, ALEJANDRO M. Eficacia y autoridad del precedente constitucional en América latina: las lecciones del Derecho Comparado, 1989-I Revista Jurídica de Buenos Aires 22, 23 (1989) (Arg.).

\footnotetext{
${ }^{30}$ The quote is part of an interesting survey of Louisiana judges. See Mary Garvey Algero, The Sources of Law and the Value of Precedent: A Comparative and Empirical Study of a Civil Law State in a Common Law Nation, 65 LA. L. REv. 775, 810 (2005).

${ }^{31}$ See Alberto F. Garay, supra note 19, 214-215; 236-238 (explaining the situation in Argentina).

${ }^{32}$ See Santiago Legarre, supra note 4,788-791 (commenting on the effect of political interferences in the role of Argentine courts).
} 
GARVEY ALGERO, MARY. The Sources of Law and the Value of Precedent: A Comparative and Empirical Study of a Civil Law State in a Common Law Nation, 65 LA. L. REv. 775, 810 (2005).

GOODHART, ARTHUR L. Precedent in English and Continental Law 50 Law Quarterly Review 40, 41 (1934).

HART, H. L. A. The Concept of Law, (Oxford U. Press, 2d ed. 1994).

LEGARRE, SANTIAGO. A Departure from the Rationale Behind the American System in the Argentine Constitution, 16 Rechtsgeschichte, Zeitschrift des Max-Planck-Instituts für europäische Rechtsgeschichte, (2010).

LEGARRE, SANTIAGO. "New Trends in Latin American Constitutionalism: an Overview" 4 Notre Dame Journal of International \& Comparative Law 1 (2014).

LEGARRE, SANTIAGO. Precedent in Argentine Law, Loyola L. Rev. 781 (2011).

LEGARRE, SANTIAGO and RIVERA JR., JULIO C. La obligatoriedad atenuada de los fallos de la Corte Suprema y el stare decisis vertical, 2009-E L.L. 820, 821 (2009) (Arg.).

LEGARRE, SANTIAGO and RIVERA JR., JULIO C. La obligatoriedad de los fallos de la Corte Suprema de Justicia de la Nación desde la perspectiva de los tribunales inferiores in LA PRIMACÍA DE LA PERSONA, 1109 (Jaime Arancibia Mattar \& José Ignacio Martínez Estay eds. LegalPublishing-AbeledoPerrot 2009).

LEGARRE, SANTIAGO and RIVERA JR., JULIO C. Nature and Dimensions of Stare Decisis, in Essays in Honor of Saúl Litvinoff, (Olivier Moréteau, Julio Romanach Jr. \& Alberto Luis Zuppi eds. Claitor 2008).

NINO, CARLOS S. Un país al margen de la ley, Ariel, Madrid, 2005.

PEREIRA MENAUT, ANTONIO-CARLOS. Temas de Derecho Constitucional Español: Una Visión Problemática, (Follas Novas, Santiago de Compostela, 1996).

SAGÜÉS, NÉSTOR PEDRO. Eficacia vinculante o no vinculante de la jurisprudencia de la Corte Suprema de Justicia de la Nación, E.D. (1981) (Arg.).

ZWEIGERT, KONRAD and KÖTZ, HEIN, Introduction to Comparative Law, third revised edition, Clarendon Press, Oxford, 1998 (translation from German by T. Weir), 260.

\section{Author Biography}

Santiago Legarre LL.B., Universidad Católica Argentina; M.St., Oxford; Ph.D., Universidad de Buenos Aires. Professor of Law, Universidad Católica Argentina; Independent Researcher, CONICET; Visiting Professor, Notre Dame Law School (USA) and Strathmore Law School (Kenya). 